\title{
THE PRINCIPLES ESTABLISHED \\ BY THE RECOMMENDATION CM/REC(2017)5 ON STANDARDS FOR E-VOTING APPLIED TO OTHER CHANNELS OF REMOTE VOTING
}

by

ROBERT MÜLLER-TÖRÖK*

E-voting is highly suspicious to many citizens and institutions. Past pilot implementations ended before Supreme Courts and mostly not in favour of e-voting. Beside these political and legal battles regarding e-voting, postal voting seems to be commonly accepted and not in question. Motivated by a landmark ruling of the Austrian Constitutional Court in 2016, ${ }^{1}$ which led to the revocation of the run-off elections result due to irregularities with postal voting, this paper analyses whether current postal voting regulations and standards in Germany comply to the principles established by the latest Council of Europe (CoE) recommendation on standards for e-voting. Both voting channels are channels for remote voting, hence principles established for one channel must, in the view of the author, also be fully applicable for the other channel. This paper applies the standards set by the recommendation to e-voting to the more commonly used remote voting channel postal voting and concludes that most of these standards cannot be met.

\section{KEY WORDS}

Elections, E-voting, Internet Voting, Postal Voting

mueller-toeroek@hs-ludwigsburg.de, Professor, University of Public Administration and Finance Ludwigsburg, Reuteallee 36, D-71634 Ludwigsburg, Germany.

1 Verfassungsgerichtshof, W I 6/2016-125, 1 July 2016. [online] Available from: https://www.ris. bka.gv.at/Dokumente/Vfgh/JFT_20160701_16W_I00006_00/JFT_20160701_16W_I00006_00. pdf [Accessed 31 May 2018]. 


\section{INTRODUCTION}

The Council of Europe (CoE) in 2004 issued a recommendation $\operatorname{Rec}(2004) 11$ which was until 2017, in the absence of any regulations in most of the national constitutions on e-voting, the yardstick to decide whether any e-voting did meet democratic standards. Due to technical progress and a significant number of e-voting pilots in many member states of the Council of Europe, the recommendation was updated in 2017. The main consideration can be found in the preamble:

"Aware of concerns about potential security, reliability or transparency problems of e-voting systems". ${ }^{2}$

These concerns exist, especially after several bad experiences with e-voting, namely:

- The Austrian Constitutional Court annulled an election where e-voting was used for the first (and last) time in Austria in 2009; ${ }^{3}$

- The Finnish Supreme Administrative Court annulled election results and ordered the elections to be repeated paper-based after a failed e-voting; ${ }^{4}$

- Several disappointing reports on e-voting pilots at municipal elections in the UK published by the Electoral Commission in $2007 ;^{5}$

2 Recommendation CM/Rec(2017)5 of the Committee of Ministers to member States on standards for e-voting. Council of Europe, p. 2.

3 Verfassungsgerichtshof, V 85-96/11-15,13 December 2011. [online] Available from: https://www. vfgh.gv.at/downloads/VfGH_V_85-96-11_e-voting.pdf [Accessed 31 May 2018].

4 Decision KHO:2009:39 (687/1/09), Supreme Administrative Court of Finland, 9 April 2009. [online]. Available from: https://www.finlex.fi/fi/oikeus/kho/vuosikirjat/2009/200900899 [Accessed 2 November 2018]; EFFI (Electronic Frontier Finland). A Report on the Finnish E-voting Pilot. [online] Available from: https://www.verifiedvoting.org/wp-content/uploads/ 2014/09/Finland-2008-EFFI-Report.pdf [Accessed 31 May 2018].

5 Actica Consulting. Technical Evaluation of Sheffield City Council e-voting Pilot 2007. [online] Available from: http://www.electoralcommission.org.uk/_data/assets/electoral_commis sion_pdf_file/0020/16193/Actica_Sheffield_27247-20138_E_ $\mathbf{N}_{2}$ S_W__.pdf [Accessed 31 May 2018]; Actica Consulting. Summary of Technical Assessments of May 2007 e-voting Pilots. [online] Available from: http://www.electoralcommission.org.uk/_data/assets/electoral_ commission_pdf_file/0018/16191/Actica_Summary_27244-20136_E__N_S_W_.pdf [Accessed 31 May 2018]; Actica Consulting. Technical Evaluation of Swindon Borough Council e-voting Pilot 2007. [online] Available from: http://www.electoralcommission.org.uk/_data/ assets/electoral_commission_pdf_file/0005/16196/Actica_Swindon_27245-20141_E_ $\bar{N} \_$__ _W_.pdf [Accessed 31 May 2018]; Actica Consulting. Technical Evaluation of $\overline{R u s h m o o r ~}$ Borough Council e-voting Pilot 2007. [online] Available from: http://www.electoralcommis sion.org.uk/_data/assets/electoral_commission_pdf_file/0019/16192/Actica_Rushmoor_272 48-20137_E____S_W_.pdf [Accessed 31 May 2018]. 
- $\quad$ Norway cancelled before usage. ${ }^{6}$

Setting aside the technical issues, which are not the focus of this paper, it is obvious that e-voting ${ }^{7}$ and postal voting are two different voting channels for remote voting. If a renowned and distinguished institution like the Council of Europe defines requirements a remote voting channel A must meet, it seems obvious that voting channel B must meet them at least in principle, otherwise one channel is not as reliable as the other, so in legal terminology: preferred. If, for instance the recommendation on e-voting requires that

"The voter shall receive confirmation by the system that the vote has been cast successfully and that the whole voting procedure has been completed," 8

the question arises whether postal voting also complies with this requirement.

It does not make much sense to require a new remote voting channel, namely e-voting, to fulfil requirements an established remote voting channel, namely postal voting does not fulfil, not even at a much lower level.

The paper consists of a commented listing of some key requirements of the recommendation in Section 2, which includes an analysis as to whether these requirements are met by postal voting in Germany. Section 3 summarizes in brief, what immediate changes to postal voting must become effective, to meet this requirements. Section 4 opens the discussion, whether it seems acceptable to permit one remote voting channel to be preferred over another and what conclusions should be drawn.

The paper intends to start a discussion on legal, process and technical issues associated with postal voting.

Regarding the scientific literature on this topic, there are only a few sources, most of them quoted in the paper. In Germany, election fraud in general and issues of remote voting in particular are not discussed. Standard textbooks dealing with elections, like e.g. Nohlen, contain just

6 BBC News. (2014) E-voting Experiments End in Norway Amid Security Fears. 27 June. [online] Available from: https://www.bbc.com/news/technology-28055678 [Accessed 4 November 2018].

$7 \quad$ E-voting in this paper means voting via the Internet.

8 Recommendation $C M / \operatorname{Rec}(2017) 5$ of the Committee of Ministers to member States on standards for e-voting. Council of Europe, p. 4 . 
a few sentences on postal voting and e-voting within a 588-page-volume ${ }^{9}$ without raising any issues. Ritter and Niehuss, who provide the analyses for elections after 1945, also fail to raise the issue of fraud. ${ }^{10}$ Finally, what may arguably be the German standard textbook on Election Research, Falter/Schoen fails to include a single line on election fraud or issues with remote voting. The index does not even contain the word "Wahlbetrug", which means election fraud. ${ }^{11}$ The standard legislative commentary on the German election law contains only one minor remark in the context of postal voting, which is referred to later in the text.

\section{KEY REQUIREMENTS ON E-VOTING DERIVED FROM THE CM/REC(2017)5}

The requirements, called standards in CoE-terminology, are grouped into thematic sections from I to VIII. Of course, they are focused on e-voting, but at least in principle they must be applicable to any other form of remote voting.

\subsection{UNIVERSAL SUFFRAGE}

The standards here are fully applicable to e-voting, but do not raise any issues except for Standard 3:

"Unless channels of remote e-voting are universally accessible, they shall be only an additional and optional means of voting."

If we consider an election like the "Sozialwahl" in Germany, where people elect representatives in Social Security Councils, this election takes place in one channel only: postal voting. ${ }^{12}$ The question arises as to what "universally accessible" means. The Explanatory Memorandum gives us the answer:

\footnotetext{
Nohlen, D. (2014) Wahlrecht und Parteiensystem - Zur Theorie und Empirie der Wahlsysteme. 7., überarbeitete und aktualisierte Auflage. Lizenzausgabe für die Bundeszentrale für politische Bildung, Verlag Barbara Budrich, Opladen/Toronto, p. 46.

10 Ritter, G. A. and Niehuss, M. (1991) Wahlen in Deutschland 1946-1991, C.H. Beck, München; Ritter, G. A. and Niehuss, M. (1995) Wahlen in Deutschland 1991-1994, C.H. Beck, München.

11 Falter, J. W. and Schoen H. (2014) Handbuch Wahlforschung. 2., überarbeitete Auflage. Springer VS, Wiesbaden, p. 891.

12 The "Sozialwahl" has an electorate of some 51 mio. People (see Soziale Selbstverwaltung. [online] Available from: https://www.sozialwahl.de/sozialwahl/die-sozialwahl-auf-einenblick/ [Accessed 31 May 2018]).
} 


\begin{abstract}
"However, offering the remote e-voting channel exclusively restricts accessibility, given the fact that the channel, namely internet, is not universally accessible for the time being. This provision aims at protecting the voter so that he or she is offered a means of voting which is effectively available to him or to her."13
\end{abstract}

Unfortunately postal voting is not universally accessible as Müller-Török and Pautsch have pointed out. ${ }^{14}$ There are severe differences between different states of the world in delivery times and delivery methods, which are not taken into account by today's German postal voting regime. Registered mail with delivery to the identified addressee only is not available in e.g. Argentine, Brazil, Chile, China and India while the delivery time indications are between 10 and 18 working days. ${ }^{15}$ This, due to the time-limits in the law, effectively hinders any postal voting. These issues, as Pautsch and Müller-Török discussed, lead to a situation where it depends on stochastic terms whether a postal ballot finds its voter and the way back within the timeframe stipulated by the election procedures and laws and whether it is counted or not. The oversea voters do not have another channel than postal voting- because it is unthinkable that e.g. a German citizen residing in Hawaii will fly to San Francisco to vote at the competent German Consulate - at his or her own expense. So at least with a view on the overseas ballot, ${ }^{16}$ postal voting does not meet the requirement raised by the recommendation. In the literature on German elections there is in only one single publication concern raised with a view to privatization of domestic postal services, but the issue of overseas voters

13 Explanatory Memorandum to Recommendation CM/Rec(2017)5 of the Committee of Ministers to member States on standards for e-voting. Document Number CM(2017)50-add1final. Council of Europe, p. 6.

14 Pautsch, A. and Müller-Török, R. (2015) Die grenzüberschreitende Zustellung von Briefwahlunterlagen vor den Schranken des Völkerrechts - Eine übersehene Problematik?. Zeitschrift für Rechtspolitik, 3, pp. 88-90, p. 89; Müller-Török, R. and Pautsch, A. (2015) Stochastische Verfälschungen von Wahlergebnissen bei grenzüberschreitender Briefwahl?. Verwaltung und Management, 4, pp. 192-197, p. 196; Prosser, A., Pautsch, A. and Müller-Török, R. Legal Aspects of Cross-Border Delivery of Voting Documents A Neglected Issue?. In: Proceedings of the 2015 2nd International Conference on Electronic Governance and Open Society: Challenges in Eurasia, ACM New York NY 2015, pp. 123.

15 For the delivery time estimates see Länderinformationen und internationale Brieflaufzeiten. [online] Available from: https://www.deutschepost.de/de/b/briefe-ins-ausland/laender informationen.html; a timely return of the postal ballot cannot be guaranteed such within the deadlines set by the electoral laws and authorities.

16 In the days before the Bavarian Federal State Assembly Elections, which took place on October 14th, 2018, a doctor's prescription needed five full days to be delivered within the City of Munich from a General Practitioner to the author. This may sound anecdotic, but raises serious questions in the context of postal voting. 
is totally neglected. ${ }^{17}$ And, with a view on the above mentioned "Sozialwahl" it does in no way meet this requirement.

\subsection{EQUAL SUFFRAGE}

\section{Standard 7 states:}

"Unique identification of voters in a way that they can unmistakably be distinguished from other persons shall be ensured."

This standard seems, at first glance, to be fulfilled by postal voting in Germany, but with a view to the two explanatory notes, it becomes ambiguous:

"The voters' registers therefore need to provide means to avoid digital twins - i.e. persons holding the same identification data. In cases where central voters' registers are used, unique identification may implicitly be given by the entry of the person in the database. With interconnected voters' registers additional means may be necessary."

In Germany the voters' registers are decentralized, but not interconnected. If we take Baden-Württemberg for example, the provisions in $\S 10 \mathrm{GemO}$ state that the mayor of each municipality may keep the voter register in an electronic manner - but he is not legally obliged to. No mandatory formal checks for duplicates over community boundaries takes place. The very same appears for the elections to the European Parliament, where Balthasar and Müller-Török have shown that no reconciliation over Member States boundaries takes place, ${ }^{18}$ despite legal requirements in European Union law. ${ }^{19}$

17 Schreiber, W.; Hahlen, J. and Strelen, K.-L. (2017) BWahlG Kommentar zum Bundeswahlgesetz unter Einbeziehung des Wahlprüfungsgesetzes, des Wahlstatistikgesetzes, der Bundeswahlordnung und sonstiger wahlrechtlicher Nebenvorschriften. 10., vollständig neubearbeitete Auflage. Carl Heymanns Verlag, p. 614.

18 In Germany, there was the famous case of Giovanni di Lorenzo, a renowned newspaper journalist, who voted twice in 2014 with his Italian and German passport on the Italian and German ballot. Charges against him were dropped after he agreed to pay a fine (see Die Welt. (2014) Verfahren gegen "Zeit" - Chef di Lorenzo eingestellt. 18 November. [online] Available from: https://www.welt.de/politik/deutschland/article134483671/ Verfahren-gegen-Zeit-Chef-di-Lorenzo-eingestellt.html [Accessed 1 September 2018]).

19 Balthasar, A. and Müller-Török, R. Ein Vorschlag zur Effektuierung des Artikels 13 der Richtlinie 93/109/EG. In: Tagungsband des 14. Internationalen Rechtsinformatik Symposions - IRIS 2011, 24.-26. Februar 2011, Salzburg. 
Standard 8 states:

"The e-voting system shall only grant a user access after authenticating her/him as a person with the right to vote,"

and looks, at first glance, not applicable for postal voting. The respective explanatory note says:

"In cases where anonymous voting tokens prove that a voter is eligible to vote, identification of the voter may not be required at this point as it has already taken place at an earlier stage, namely when the specific token is assigned to a specific voter."

The postal ballot is definitely an anonymous voting token in the meaning of the recommendation. Here a major question arises: Was the voter identified before he was handed over the postal ballot by the postman? Unfortunately, the application for postal voting in Germany consists of three steps, which do not require much identification as shown below:

1. The voter receives a postcard or letter by non-registered mail in his or her mailbox, which enables him or her to require a postal ballot. This can be done without the postcard/letter, even by plain fax or e-mail, ${ }^{20}$ in this case jump step 2;

2. The voter ticks a box, signs the postcard or letter and sends it to his or her Election Authority. Note that an address different from the voter's address in the voter roll can be stated. The postal ballot is sent to this new address without further inquiries;

3. The Election Authority sends the postal ballot to the address stated on the request with non-registered mail. ${ }^{21}$

As Stein and Müller-Török have shown, a signature is a non-secure proof of identity in an election context, because it is expensive to verify and leads to a less-than-100 percent level of likelihood that the person who signed is

20 The Federal Returning Officer suggests this at his website when explaining the process of postal voting (see Briefwahl. [online] Available from: https://www.bundeswahlleiter.de/ bundestagswahlen/2017/informationen-waehler/briefwahl.html\#967be3c2-d7a4-46c4-8d771784f3fce9f2 [Accessed 1 September 2018]).

21 The only occasions in the life of the author in Germany (1997-2018), where a postal ballot was sent by registered mail with a mandatory proof of identity were when receiving his ballots for the Austrian Parliamentary and Presidential Elections. For German elections the ballots were never sent registered mail nor had he to proof his identity to postmen. 
the person in question. ${ }^{22}$ A mailbox is, because of the lack of standardized and lockable mailboxes in Germany, not a safe place. It is easy to get an envelope out of a mailbox without a key, because no legal provision requires mailboxes to hinder third-party access. In Austria, on the other hand, § 34 PMG requires:

"The mailbox must be such that postal shipments are protected against third-party access by an appropriate protection" (my translation).

In Germany, there was a major case of election fraud regarding applications for postal voting at a local election. A farmer in Bavaria filled in hundreds of such request forms for her Romanian farmhands and managed to submit the postal ballots. Election authorities nullified the election and the criminal lawsuit is still pending. ${ }^{23}$

It is obvious that this protocol is not safe against misuse. Also the standard legislative commentary acknowledges these shortcomings, namely:

- A postal ballot can easily be requested by third parties in the name of the voter;

- The possibility of stating a different address the ballot shall be sent to;

- All documents included can easily be forged or copied;

- Issues with elderly or (mentally) disabled people in nursing homes. $^{24}$

Standard 9 requires that only the appropriate number of votes per voter is cast, stored and counted. "One person, one vote" is mentioned in the explanatory note but, in the opinion of the author, violated in one

22 Stein, R. and Müller-Török, R. (2010) Die Europäische Bürgerinitiative aus Sicht nationaler Wahlbehörden: Probleme der Verifikation von Unterstützungserklärungen in der Praxis. Verwaltung und Management, 5, pp. 255-262.

23 Landgericht Regensburg. (2018) Strafverfahren wegen Verdachts der Wahlmanipulation in Geiselhöring. [press release] 15 October. Available from: https://www.justiz.bayern.de/ gerichte-und-behoerden/landgericht/regensburg/presse/2018/7.php [Accessed 2 November 2018]. The assumption of innocence is not applicable; because the election was already nullified by the election authority (see Die Welt. (2014) Bayerischer Kreis muss wegen Fälschung neu wählen. 2 October. [online] Available from: https://www.welt.de/politik/ deutschland/article132875498/Bayerischer-Kreis-muss-wegen-Faelschung-neu-waehlen. html [Accessed 2 November 2018]).

24 Schreiber, W.; Hahlen, J. and Strelen, K.-L. (2017) BWahlG Kommentar zum Bundeswahlgesetz unter Einbeziehung des Wahlprüfungsgesetzes, des Wahlstatistikgesetzes, der Bundeswahlordnung und sonstiger wahlrechtlicher Nebenvorschriften. 10., vollständig neubearbeitete Auflage. Carl Heymanns Verlag, p. 613. 
special situation: If the voter dies before election day, he or she can of course not vote at the polling station but his or her postal vote cast before his or her dying day and well before election day is counted if mailed. This may sound irrelevant at the first glance, but if you consider narrow results in a constituency and some 20 days between receiving postal ballots and Election Day this may well become relevant. ${ }^{25}$ At least it seems obvious, that voters cannot be treated equally dependent of the voting channel chosen.

\subsection{FREE SUFFRAGE}

Standard 15 to 17 are the most crucial requirements when they are applied to existing postal voting. 15 states:

"The voter shall be able to verify that his or her intention is accurately represented in the vote and that the sealed vote has entered the electronic ballot box without being altered. Any undue influence that has modified the vote shall be detectable,"

while 16 requires:

"The voter shall receive confirmation by the system that the vote has been cast successfully and that the whole voting procedure has been completed."

And 17 finally asks:

"The e-voting system shall provide sound evidence that each authentic vote is accurately included in the respective election results. The evidence should be verifiable by means that are independent from the e-voting system."

As the explanatory notes show, a chain of trust must be established. Individual verifiability by the voter, as demanded by explanatory note 55 , cannot exist in a postal voting regime where ballots are sent to the Election Authority by non-registered mail and in envelopes, which must not carry the address of the voter. So it is also impossible to tell whether a ballot from an individual voter arrived and was cast and counted, let alone the detection of unlawful alterations. The current postal voting in Germany is like a letter in a bottle, thrown into the sea: Once the voter put his or her envelope into the post box, no one can tell whether it arrived and whether it

25 Heiner Geißler, former chairman and long-term Member of Parliament of the German Christian Democratic Party died in his 88th year on 12 September 2017, 12 days before Election Day. He is likely to have voted by postal voting with his vote being counted. 
was counted or not. As the repealed Austrian Presidential Elections of 2016 have shown, irregularities do occur even in the Electoral Commissions when opening the envelopes with the postal ballots and counting. ${ }^{26}$ The requirement that any undue influence shall be detectable, does not fully apply to postal voting. As Schreiber et al. pointed out, election authorities in Germany do not even check whether incoming postal ballots match postal ballots sent to voters ${ }^{27}$ and all documents can easily be copied and/or modified. $^{28}$

\subsection{SECRET SUFFRAGE}

Standard 19 is an obvious necessity; nevertheless, it can easily be violated when postal voting from overseas voters occurs. It states that

"the secrecy of the vote is respected at all stages of the voting procedures."

As Pautsch and Müller-Török have shown, jurisdiction of e.g. the US Supreme Court is not compatible with this (European) standard. In United States vs. Ramsey, the court ruled regarding the opening and searching of post sent to Ramsey from abroad:

"[...] That searches made at the border, pursuant to the longstanding right of the sovereign to protect itself by stopping and examining persons and property crossing into this country, are reasonable simply by virtue of the fact that they occur at the border should, by now, require no extended demonstration. “29

And with even more clarity in the same case:

"Border searches, then, from before the adoption of the Fourth Amendment, have been considered to be "reasonable" by the single fact that the person or item in question had entered into our country from outside. There has never been any additional requirement that the reasonableness of a border search depended on the existence of probable cause. This longstanding

26 Verfassungsgerichtshof, $V$ 85-96/11-15, 13 December 2011. [online] Available from: https://www.vfgh.gv.at/downloads/VfGH_V_85-96-11_e-voting.pdf [Accessed 31 May 2018].

27 Schreiber, W.; Hahlen, J. and Strelen, K.-L. (2017) BWahlG Kommentar zum Bundeswahlgesetz unter Einbeziehung des Wahlprüfungsgesetzes, des Wahlstatistikgesetzes, der Bundeswahlordnung und sonstiger wahlrechtlicher Nebenvorschriften. 10., vollständig neubearbeitete Auflage. Carl Heymanns Verlag, p. 613.

28 Ibid.

29 United States vs. Ramsey (1977) 431 U.S. 606. 
recognition that searches at our borders without probable cause and without a warrant are nonetheless "reasonable" has a history as old as the Fourth Amendment itself." 30

This standard can be obeyed to in an e-voting environment, where encryption by e.g. TLS/SSL hinders U.S. Postal Inspection Service, Customs and Border Protection and other agencies to open and search the e-voting ballot, ${ }^{31}$ but no one can hinder the before mentioned agencies to open and search postal voting ballots for contraband, such breaking the secrecy of the vote. Collecting all postal votes from the US at a German consulate and sending it to Germany with diplomatic mail seems not to be a viable option.

Setting aside the lawful interception of postal voting documents, of course Secret Suffrage can be breached illegally, e.g.by opening the envelopes and closing them again. In the former GDR the State Security Service ("Staatssicherheit" or short "Stasi") opened nearly each letter to and from abroad, read it and closed it in a manner which nearly perfectly camouflaged the fact that it had been opened. ${ }^{32}$ A postal ballot does not have sufficient precautions against such measures. Even if it were not possible to close it again, the vote would be lost - that the voter cannot learn that his or her vote was lost seems to be an obvious violation of standard 15 , namely:

"The voter shall be able to verify that his or her intention is accurately represented in the vote and that the sealed vote has entered the electronic ballot box without being altered. Any undue influence that has modified the vote shall be detectable."

30 Ibid.

31 In this paper the author lets aside the issues associated with more restrictive internet usage regimes like e.g. The Great Firewall of China (see Bloomberg. (2018) The Great Firewall of China. 6 November. [online] Available from: https://www.bloomberg.com/quicktake/ great-firewall-of-china [Accessed 4 November 2018]).

32 For an introduction and legal documents of the GDR regarding this practice see the websites of the Federal Agency for Civic Education regarding the regular checks of postal shipments by the State Security Service (Allwissenheit als Ziel - Die Postkontrolle der DDR-Geheimpolizei. [online] Available from: http://www.bpb.de/geschichte/deutschegeschichte/stasi/223937/postkontrolle [as per 1 September 2018]) and of the Federal Commissioner for the Records of the State Security Service of the former German Democratic Republic (Das Recht auf Postgeheimnis. [online] Available from: https://www.demokratie-statt-diktatur.de/DSD/DE/Postgeheimnis/Aus-dem-Archiv/_node. html [as per 1 September 2018]). 
This postal voting also creates another conflict with standard 19: When posting the postal ballot into a post box, at least the following parties are able to intercept the vote:

- The person collecting the post from the box, in specific boroughs you may assume tendencies, so e.g. a conservative or nationalist postal worker could throw away postal ballots in a borough, which traditionally votes for communist, socialist or ecological parties. Since the envelope does not bear a sender's address in Germany and since the posting is not documented, there is no way to even detect this offence;

- Any other postal worker from the collection to the delivery, a number likely to be in the two-digit-range;

- Sorting machines could probably open or destroy postal ballots by mistake or, probably the worst case, leave them undelivered because of an assumed or real lack of sufficient franking;

- Staff at the election authority could make a broad variety of mistakes as the landmark case regarding Austrian Presidential Elections has shown, e.g.

Non-members of the election authority opened envelopes and took out the ballots; ${ }^{33}$

Non-members of the election authority decided whether ballots were invalid. ${ }^{34}$ They could at least theoretically, have invalidated them on their own, as the Constitutional Court argued; ${ }^{35}$

- The person who receives the postal ballots from the postal services on behalf of the election authority could destroy them or hide them away. Since there is neither a closed and reliable chain of trust, nor even some paper-based protocol requirements, the likelihood of detection is quite low.

33 Verfassungsgerichtshof, W I 6/2016-125, 1 July 2016. [online] Available from: https://www.ris. bka.gv.at/Dokumente/Vfgh/JFT_20160701_16W_I00006_00/JFT_20160701_16W_I00006_ 00.pdf [Accessed 31 May 2018]; RZ 201, 202 and 217 and several others.

34 Ibid, RZ 233 and 234.

35 Ibid, RZ 237 and 238; the whole ruling has 175 pages and the two illegal practices occurred many time in many constituencies, hence only a few were quoted here. 


\subsection{REGULATORY AND ORGANIZATIONAL REQUIREMENTS}

At the first glance, postal voting fulfils the standards of this section. A closer analysis however shows, a conflict occurs with standard 29:

"The relevant legislation shall regulate the responsibilities for the functioning of e-voting systems and ensure that the electoral management body has control over them."

As explanatory note 88 shows:

"member States not to be dependent on just a few vendors since this could result in a vendor-lock-in."

A vendor-lock-in, as described by literature ${ }^{36}$ is when a customer, in this context an election authority, is fully dependent on a vendor. This vendor is, with respect to postal voting, the Deutsche Post AG (together with many smaller postal services providers) which cannot be monitored nor controlled by election authorities and also, at a later stage, courts. The explanatory note 88 becomes even more concrete and states:

"When considering outsourcing, it is essential that those who are responsible for the elections understand what is being outsourced, why it is being outsourced and what methods and processes the vendor intends to undertake."

Explanatory note 87 adds:

"It is recommended that the relevant legislation provides for the supervisory role of the electoral management body over e-voting. The role and the responsibilities of the other parties involved should be clarified at the appropriate regulatory or contractual level."

As shown above in the section regarding secret suffrage, foreign postal services are impossible to be controlled by the Election Authorities. If we take e.g. the delivery times, Pautsch and Müller-Török have shown that they

36 Liebowitz, S. J.; Margolis, Stephen E. (1995) Path dependence, lock-in and history. Journal of Law, Economics, and Organization. 11, p. 205-226. 
are beyond any national control ${ }^{37}$ and it is obvious that no regulation nor contract other than the Convention union postale universelle ${ }^{38}$ exists.

\subsection{TRANSPARENCY AND OBSERVATION}

Transparency is an issue from the time the postal voter drops his or her ballot into the mailbox. From here on absolutely no transparency exists, because:

- The envelope bears no sender in German postal voting, hence a totally anonymous vote is being transferred (or not) totally untracked to the respective Election Authority and no one can ever tell whether it arrived, was counted etc.;

- Unlike e.g. registered mail or parcels, which can be tracked via the Internet, the postal ballot cannot be tracked.

Explanatory note no. 91 is violated, which states:

"In particular system's transparency, or the possibility to check that it is functioning properly, must be guaranteed. Member States regulate who has access to what and when and under what circumstances."

The national - and much more the foreign - postal authorities are neither transparent nor can anyone guarantee their proper functioning. Recent newspaper reports show that the Deutsche Post AG decided to introduce other days other than Sundays where no mail is delivered. If such causes a loss of a handful of ballots, the outcome of elections can be changed as e.g. in 2013 a narrow constituency for German Parliament, Märkischer Kreis II was won by a margin of 53 votes - or 27 ballots would have made a change. $^{39}$

\subsection{ACCOUNTABILITY}

These standards are obviously focused on e-voting, but if applied to postal voting, it becomes obvious that their underlying principles are violated by postal voting practice. If we take standard 37, it states:

\footnotetext{
37 Pautsch, A. and Müller-Török, R. (2015) Die grenzüberschreitende Zustellung von Briefwahlunterlagen vor den Schranken des Völkerrechts - Eine übersehene Problematik?. Zeitschrift für Rechtspolitik, 3, pp. 88-90, p. 90.

38 Convention union postale universelle. [online] Available from: http://www.upu.int/fr/lupu/ actes/actes-en-trois-volumes.html [Accessed 4 November 2018].

39 Der Bundeswahlleiter. (2014) Wahl zum Deutschen Bundestag am 22. 9. 2013, Heft 5, Teil 1, Textliche Auswertung Wahlergebnisse, p. 69, anhangtabelle 1.
} 


\begin{abstract}
"Before an e-voting system is introduced and at appropriate intervals thereafter, and in particular after any significant changes are made to the system, an independent and competent body shall evaluate the compliance of the e-voting system and of any information and communication technology (ICT) component with the technical requirements. This may take the form of formal certification or other appropriate control."
\end{abstract}

Who certified postal services? In the recent years, not only the formerly state-operated Deutsche Bundespost was transferred into a stock-exchange-listed entity Deutsche Post AG but also new, mostly local, postal service providers were founded. Some of them went bankrupt at short notice, e.g. RegioPost Pfalz GmbH that stopped postal services in February 2018 and told some 500 staff on 19 January 2018 that they are laid off with effect from 20 January 2018. ${ }^{40}$ If this were in the six weeks before a Parliamentary Election Day, irregularities would surely have occurred in postal voting. It seems notable in this context that nowadays mail, including postal ballots, is not handled by sworn officers like in the days of the Deutsche Bundespost but by low-paid staff in sub entities of the Deutsche Post AG with significantly lower wages. ${ }^{41}$ This seems to be an international trend. ${ }^{42}$ Schreiber et al. heavily criticized the privatization of postal services in the context of postal voting. ${ }^{43}$

Another standard is 39 , the requirement for auditability, namely:

"The audit system shall [...] actively report on potential issues and threats."

It is obvious that this requirement is not fulfilled by any paper-based postal system. No post box actively reports when it is damaged or shipments are

40 Karin Hurrle. (2018) Müssen entlassene Mitarbeiter nun wieder die Zeche für ein Missmanagement zahlen? Nachrichten Regional, 23 January. [online] Available from: https://www.nachrichten-regional.de/index.php/\%C3\%BCberregional/6733-regio-post-pfalz -und-regio-post-beteiligungsgesellschaft-ein-undurchsichtiges-konstrukt.html

[Accessed 4 November 2018].

${ }^{41}$ Spiegel Online. (2018) Zusteller der Deutschen Post sollen in neuen Betrieb ausgelagert werden. 12 March. [online] Available from: https:/www.spiegel.de/wirtschaft/ unternehmen/deutsche-post-zusteller-sollen-in-neuen-betrieb-ausgelagert-werden-a1197588.html

42 See e.g. The Telegraph. (2017) Threat of Royal Mail Strike Lessens as Progress Made in Union Talks. 6 December. [online] Available from: https://www.telegraph.co.uk/business/2017/12/ 06/threat-royal-mail-strike-lessens-progress-made-union-talks/

43 Schreiber, W.; Hahlen, J. and Strelen, K.-L. (2017) BWahlG Kommentar zum Bundeswahlgesetz unter Einbeziehung des Wahlprüfungsgesetzes, des Wahlstatistikgesetzes, der Bundeswahlordnung und sonstiger wahlrechtlicher Nebenvorschriften. 10., vollständig neubearbeitete Auflage. Carl Heymanns Verlag, p. 613. 
stolen out of it. No one can tell whether envelopes with postal votes are fished out of a post box, at least at the present technological standards in Germany. If we compare this to explanatory note 114, it is obvious that no Intrusion Detection System exists for postal services and that, hopefully, for registered mail, no audit trails exist as required by explanatory note 115 . Explanatory note 118, which requires:

"observers should be able to see the total number of ballots cast in real time, so that independent cross checks can be performed,"

cannot be fulfilled by a postal service based on post boxes, manual transport with trucks and no electronic tracking system at all. Concerning the other explanatory notes, we must state that none of these audit requirements can be met by postal voting. No postal system can detect voter fraud, as Isobel White has shown for the UK. ${ }^{44}$

\subsection{RELIABILITY AND SECURITY OF THE SYSTEM}

With respect to reliability and security, already the first standard no. 40 cannot be fulfilled by postal voting:

"The electoral management body shall be responsible for the respect for and

compliance with all requirements even in the case of failures and attacks."

This would mean that election authorities are in charge of all involved postal services used - even of the postal services in Thailand or Argentine, if a voter cast his or her ballot there. Access to central infrastructure (of postal services worldwide) cannot be granted to persons "authorised by the electoral management body" as standard 41 requests. Also, among others, standard 47 is impossible to fulfil, namely:

"Where incidents that could threaten the integrity of the system occur, those responsible for operating the equipment shall immediately inform the electoral management body."

would require the e.g. Argentine postal service to report to (German) election authorities when a bag of shipments is stolen, which could contain ballots for German elections. Moreover, finally standard 49 is impossible

${ }_{44}$ White, I. and Coleman, Ch. (2011) Postal Voting E Electoral Fraud, SN/PC/3667, House of Commons Library; White, I. (2015) Electoral Offences since 2010, House of Commons Library Briefing Paper Number 625. 
to be fulfilled by postal voting: Identifying votes that are affected by irregularities.

\section{IMMEDIATE CHANGES NECESSARY FOR GERMAN POSTAL VOTING}

With a view to the section above the following changes seem unavoidable necessities in order to comply with essential principles of voting:

1. Introduction of either a centralized German voter registry or automatic reconciliation of the decentralized registers to ensure effectively that no identity twin nor double-registered voter occurs. This registry must also be able to deal with people dying after having applied for postal ballots etc.;

2. Sending postal ballots to the voter by registered mail only with a mandatory and high profile proof of identity, ${ }^{45}$ thereby hindering bogus applications and theft of ballots; ${ }^{46}$

3. A mechanism shall be established where a voter may verify whether his or her vote actually arrived with the Election Authorities and entered the ballot box. This mechanism must guarantee anonymity;

4. Regarding overseas voters, the timelines and the whole legal framework must be reengineered according to the recommendations of Pautsch and Müller-Török. The risk that any other authoritarian state manipulates the cornerstone of German democracy is far too high with some 2 million German voters living abroad. If we take e.g. the preliminary results of the latest election in Germany, the one for the State Assembly of the Federal State of Hesse on October 28, 2018, the race for the second place between Social Democrats and Green Party was decided by a margin of 94 votes. $^{47}$ If only 47 ballots were different, it would have been a tie.

45 The author was handed a letter sent by registered mail today (October 16th, 2018) when opening the door w/o any proof of identity. The "signature" required consisted of "signing his name" with his pointing finger on a mobile device, some kind of touchpad. It is obvious that such a "signature" will not be highly valued in a Constitutional Court.

46 Such offences are common in e.g. the UK as shown by White and Coleman (p. 20) and White (see fn. 44). Unfortunately comparable statistics are not available for Germany. 
These measures cannot hinder third parties, e.g. spouses to steal postal ballots or violently force the voter to cast his or her vote. ${ }^{48}$ Because a mechanism like a replacing vote, which can be implemented in an e-voting system, cannot be implemented in postal voting, this risk still exists.

\section{RESUME}

To summarize, the current German (and other) regime of postal voting has one big issue, which seems to be totally underestimated regarding its effect on election results:

Once the election authority sends the postal ballot to an address (hopefully the address of the voter), it totally loses any control until the ballot returns. In the meantime, which means within a period of several weeks, the following persons/entities could have corrupted the ballot, by stealing, forging, casting their own vote on behalf of the voter etc.:

1. Postal services and their employees of Germany and all other countries affected;

2. State agencies like the above-mentioned US Customs and US Postal Inspectors but, in our days, also rogue states which want to manipulate German elections by manipulating the ballots of imprisoned German citizens;

3. Individuals, including neighbours, relatives and spouses who intercept ballots or use force to make the voter cast his or her vote in violation of voting principles.

The major problem, according to the literature, the political discussion and discussions with fellow scientists and election practitioners is that postal voting once was the rare exception, when being abroad, ill etc. Nowadays it has become a way of "convenience voting", which frees

47 Hessisches Statistisches Landesamt. (2018) Statistische Berichte, Kennziffer B VII 2-3 - 5j/18, Die Landtagswahl in Hessen am 28. Oktober 2018, Vorläufige Ergebnisse. [online] Available from: https://statistik.hessen.de/sites/statistik.hessen.de/files/BVII2-3_5j18.pdf

[Accessed 2 November 2018], p. 12; it is notable that the final result is not available on 9 November 2018 due to irregularities, mistakes and necessary recounts. The final result is expected for 16 November 2018 (see Die Welt. (2018) Es gab eine Reihe von Übermittlungs- und Eingabefehlern. 9 November. [online] Available from: https://www.welt.de/politik/deutschland/article183584926/Landtagswahl-Hessen-2018-Soerklaert-der-Wahlleiter-die-Auszaehlungspanne.html [Accessed 9 November 2018]).

48 White, I. and Coleman, Ch. (2011) Postal Voting E Electoral Fraud, SN/PC/3667, House of Commons Library, pp. 18, 27 and 33. 
the voter from the perceived burden of appearing in person at the polling station. From 1994 to 2017 the share of postal voters at the parliamentary elections in Germany has more than doubled and stands at 28.6 percent with Hamburg and Bavaria leading the way with 37.0 and 37.3 percent respectively. ${ }^{49}$ If you take e.g. the Federal State of Hamburg, it is a city with 984,926 votes cast out of approx. 1.8 Mio. inhabitants occupying some 755 square kilometres, hence it seems unreproducible that 364,213 postal voters were sick, disabled, abroad or in a comparable situation which hindered them to appear in person at the polling station. ${ }^{50}$

The major thing to do now is to start a serious scientific discussion about these issues. As shown above, the issues exist but unfortunately not the scientific publications dealing with them. So the first duty of the Social Sciences would be to provide a sound basis for a political discussion. This contribution is intended to be a stimulus starting a discussion.

\section{LIST OF REFERENCES}

[1] Actica Consulting. Summary of Technical Assessments of May 2007 e-voting Pilots. [online] Available from: http://www.electoralcommission.org.uk/_data/assets/electoral_ commission_pdf_file/0018/16191/Actica_Summary_27244-20136_E_N_S_W_.pdf [Accessed 31 May 2018].

[2] Actica Consulting. Technical Evaluation of Rushmoor Borough Council e-voting Pilot 2007. [online] Available from: http://www.electoralcommission.org.uk/_data/assets/electoral_ commission_pdf_file/0019/16192/Actica_Rushmoor_27248-20137_E_N_S_W_.pdf [Accessed 31 May 2018].

[3] Actica Consulting. Technical Evaluation of Sheffield City Council e-voting Pilot 2007. [online] Available from: http://www.electoralcommission.org.uk/_data/assets/electoral_ commission_pdf_file/0020/16193/Actica_Sheffield_27247-20138_E__N_S_W_.pdf [Accessed 31 May 2018].

[4] Actica Consulting. Technical Evaluation of Swindon Borough Council e-voting Pilot 2007. [online] Available from: http://www.electoralcommission.org.uk/_data/assets/electoral_

49 Der Bundeswahlleiter. (2017) Anteil der Briefwählerinnen und Briefwähler bei den Bundestagswahlen 1994 bis 2017 nach Ländern (auf Grundlage des amtlichen Endergebnisses), Wiesbaden. [online] Available from: https://www.bundeswahlleiter.de/ dam/jcr/b4aeabb8-7fac-473e-8581-cd718cb7a007/BTW_ab94_briefwahl.pdf [Accessed 1 September 2018].

50 Ibid. 
commission_pdf_file/0005/16196/Actica_Swindon_27245-20141_E_N_S_W_.pdf [Accessed 31 May 2018].

[5] Allwissenheit als Ziel - Die Postkontrolle der DDR-Geheimpolizei. [online] Available from: http://www.bpb.de/geschichte/deutsche-geschichte/stasi/223937/postkontrolle

[6] Balthasar, A. and Müller-Török, R. Ein Vorschlag zur Effektuierung des Artikels 13 der Richtlinie 93/109/EG. In: Tagungsband des 14. Internationalen Rechtsinformatik Symposions - IRIS 2011, 24.-26. Februar 2011, Salzburg.

[7] BBC News. (2014) E-voting Experiments End in Norway Amid Security Fears. 27 June. [online] Available from: https://www.bbc.com/news/technology-28055678

[Accessed 4 November 2018].

[8] Bloomberg. (2018) The Great Firewall of China. 6 November. [online]. Available from: https://www.bloomberg.com/quicktake/great-firewall-of-china [Accessed 4 November 2018].

[9] Briefwahl. [online] Available from: https://www.bundeswahlleiter.de/bundestagswahlen/ 2017/informationen-waehler/briefwahl.html\#967be3c2-d7a4-46c4-8d77-1784f3fce9f2 [Accessed 1 September 2018].

[10] Convention union postale universelle. [online] Available from: http://www.upu.int/fr/ lupu/actes/actes-en-trois-volumes.html [Accessed 4 November 2018].

[11] Das Recht auf Postgeheimnis. [online] Available from: https://www.demokratie-stattdiktatur.de/DSD/DE/Postgeheimnis/Aus-dem-Archiv/_node.html

[12] Decision KHO:2009:39 (687/1/09), Supreme Administrative Court of Finland, 9 April 2009. [online] Available from: https://www.finlex.fi/fi/oikeus/kho/vuosikirjat/2009/200900899 [Accessed 2 November 2018].

[13] Der Bundeswahlleiter. (2014) Wahl zum Deutschen Bundestag am 22. 9. 2013, Heft 5, Teil 1, Textliche Auswertung Wahlergebnisse, p. 69, anhangtabelle 1.

[14] Der Bundeswahlleiter. (2017) Anteil der Briefwählerinnen und Briefwähler bei den Bundestagswahlen 1994 bis 2017 nach Ländern (auf Grundlage des amtlichen Endergebnisses), Wiesbaden. [online] Available from: https://www.bundeswahlleiter.de/ dam/jcr/b4aeabb8-7fac-473e-8581-cd718cb7a007/BTW_ab94_briefwahl.pdf [Accessed 1 September 2018].

[15] Die Welt. (2014) Bayerischer Kreis muss wegen Fälschung neu wählen. 2 October. [online] Available from: https://www.welt.de/politik/deutschland/article132875498/BayerischerKreis-muss-wegen-Faelschung-neu-waehlen.html [Accessed 2 November 2018]. 
[16] Die Welt. (2014) Verfahren gegen "Zeit" - Chef di Lorenzo eingestellt. 18 November. [online] Available from: https://www.welt.de/politik/deutschland/article134483671/ Verfahren-gegen-Zeit-Chef-di-Lorenzo-eingestellt.html [Accessed 1 September 2018].

[17] Die Welt. (2018) Es gab eine Reihe von Übermittlungs- und Eingabefehlern. 9 November. [online] Available from: https://www.welt.de/politik/deutschland/article183584926/ Landtagswahl-Hessen-2018-So-erklaert-der-Wahlleiter-die-Auszaehlungspanne.html [Accessed 9 November 2018].

[18] EFFI (Electronic Frontier Finland). A Report on the Finnish E-voting Pilot. [online] Available from: https://www.verifiedvoting.org/wp-content/uploads/2014/09/Finland2008-EFFI-Report.pdf [Accessed 31 May 2018].

[19] Explanatory Memorandum to Recommendation CM/Rec(2017)5 of the Committee of Ministers to member States on standards for e-voting. Document Number CM(2017)50-add1final. Council of Europe.

[20] Falter, J. W. and Schoen H. (2014) Handbuch Wahlforschung. 2., überarbeitete Auflage. Springer VS, Wiesbaden.

[21] Hessisches Statistisches Landesamt. (2018) Statistische Berichte, Kennziffer B VII 2-3 - 5j/18, Die Landtagswahl in Hessen am 28. Oktober 2018, Vorläufige Ergebnisse. [online] Available from: https://statistik.hessen.de/sites/statistik.hessen.de/files/BVII2-3_5j18.pdf [Accessed 2 November 2018].

[22] Karin Hurrle. (2018) Müssen entlassene Mitarbeiter nun wieder die Zeche für ein Missmanagement zahlen? Nachrichten Regional, 23 January. [online] Available from: https://www.nachrichten-regional.de/index.php/\%C3\%BCberregional/6733-regiopost-pfalz-und-regio-post-beteiligungsgesellschaft-ein-undurchsichtiges-konstrukt.html [Accessed 4 November 2018].

[23] Länderinformationen und internationale Brieflaufzeiten. [online] Available from: https://www.deutschepost.de/de/b/briefe-ins-ausland/laenderinformationen.html

[24] Landgericht Regensburg. (2018) Strafverfahren wegen Verdachts der Wahlmanipulation in Geiselhöring. [press release] 15 October. Available from: https://www.justiz.bayern.de/ gerichte-und-behoerden/landgericht/regensburg/presse/2018/7.php [Accessed 2 November 2018].

[25] Liebowitz, S. J.; Margolis, Stephen E. (1995) Path dependence, lock-in and history. Journal of Law, Economics, and Organization. 11. 
[26] Müller-Török, R. and Pautsch, A. (2015) Stochastische Verfälschungen von Wahlergebnissen bei grenzüberschreitender Briefwahl?. Verwaltung und Management, 4.

[27] Nohlen, D. (2014) Wahlrecht und Parteiensystem - Zur Theorie und Empirie der Wahlsysteme, 7., überarbeitete und aktualisierte Auflage. Lizenzausgabe für die Bundeszentrale für politische Bildung, Verlag Barbara Budrich, Opladen/Toronto.

[28] Pautsch, A. and Müller-Török, R. (2015) Die grenzüberschreitende Zustellung von Briefwahlunterlagen vor den Schranken des Völkerrechts - Eine übersehene Problematik?. Zeitschrift für Rechtspolitik, 3.

[29] Prosser, A., Pautsch, A. and Müller-Török, R. Legal Aspects of Cross-Border Delivery of Voting Documents - A Neglected Issue?. In: Proceedings of the 2015 2nd International Conference on Electronic Governance and Open Society: Challenges in Eurasia, ACM New York NY 2015.

[30] Recommendation CM/Rec(2017)5 of the Committee of Ministers to member States on standards for e-voting. Council of Europe.

[31] Ritter, G. A. and Niehuss, M. (1991) Wahlen in Deutschland 1946-1991, C.H. Beck, München.

[32] Ritter, G. A. and Niehuss, M. (1995) Wahlen in Deutschland 1991-1994, C.H. Beck, München.

[33] Schreiber, W.; Hahlen, J. and Strelen, K.-L. (2017) BWahlG Kommentar zum Bundeswahlgesetz unter Einbeziehung des Wahlprüfungsgesetzes, des Wahlstatistikgesetzes, der Bundeswahlordnung und sonstiger wahlrechtlicher Nebenvorschriften. 10., vollständig neubearbeitete Auflage. Carl Heymanns Verlag.

[34] Soziale Selbstverwaltung. [online] Available from: https://www.sozialwahl.de/sozialwahl/ die-sozialwahl-auf-einen-blick/ [Accessed 31 May 2018].

[35] Spiegel Online. (2018) Zusteller der Deutschen Post sollen in neuen Betrieb ausgelagert werden. 12 March. [online] Available from: https://www.spiegel.de/wirtschaft/ unternehmen/deutsche-post-zusteller-sollen-in-neuen-betrieb-ausgelagert-werden-a1197588.html

[36] Stein, R. and Müller-Török, R. (2010) Die Europäische Bürgerinitiative aus Sicht nationaler Wahlbehörden: Probleme der Verifikation von Unterstützungserklärungen in der Praxis. Verwaltung und Management, 5. 
[37] The Telegraph. (2017) Threat of Royal Mail Strike Lessens as Progress Made in Union Talks. 6 December. [online] Available from: https://www.telegraph.co.uk/business/ 2017/12/06/threat-royal-mail-strike-lessens-progress-made-union-talks/

[38] United States vs. Ramsey (1977) 431 U.S. 606.

[39] Verfassungsgerichtshof, $V$ 85-96/11-15, 13 December 2011. [online] Available from: https://www.vfgh.gv.at/downloads/VfGH_V_85-96-11_e-voting.pdf [Accessed 31 May 2018].

[40] Verfassungsgerichtshof, W I 6/2016-125, 1 July 2016. [online] Available from: https://www.ris.bka.gv.at/Dokumente/Vfgh/JFT_20160701_16W_I00006_00/JFT_20160701 _16W_I00006_00.pdf [Accessed 31 May 2018].

[41] White, I. (2015) Electoral Offences since 2010, House of Commons Library Briefing Paper Number 625.

[42] White, I. and Coleman, Ch. (2011) Postal Voting \& Electoral Fraud, SN/PC/3667, House of Commons Library. 